\title{
ONTHE BRAZILIAN Prosierola (HYMENOPTERA, BETHYLIDAE), WITH DESCRIPTION OF A NEW SPECIES FROM AMAZONAS, BRAZIL.
}

\section{Gustavo SCHIFFLER $^{1,2}$, Celso Oliveira AZEVEDO ${ }^{1}$}

ABSTRACT - Prosierola rotunda sp. nov. from northern Brazil is described and illustrated. Additional specimens of $P$. lata (Cameron, 1888) were examined with species variation analyzed and new distribution data are added.

Key-words: Bethylidae, Brazil, Hymenoptera, Prosierola, Systematics.

Prosierola (Hymenoptera, Bethylidae) Brasileiros, com Descrição de Uma Espécie Nova do Amazonas, Brasil.

RESUMO - É descrita e ilustrada Prosierola rotunda sp. nov. do norte do Brasil. Foram examinados novos espécimes de $P$. lata (Cameron, 1888), com a análise das variações morfológicas e inclusão novos dados de distribuição.

Palavras-chave: Bethylidae, Brasil, Hymenoptera, Prosierola, Sistemática.

Prosierola Kieffer, 1905, is a Bethylinae genus (Hymenoptera, Bethylidae) promptly recognized by having two pits on the anterior area of propodeal disc (Azevedo, 1991). It includes only eight species, all of them restricted to New World. There are two species recorded from Brazil, $P$. lata (Cameron, 1888) from Mato Grosso and Santa Catarina States, and P. nasalis (Westwood, 1874) from Distrito Federal. In this contribution, a new species from Amazonas State is described and illustrated.

The material examined was provided by the following institutions: DCBU - Universidade Federal de São Carlos, Brazil (A.M. Penteado-Dias); INPA - Instituto Nacional de Pesquisas da Amazônia, Brazil (C. Magalhães); UFES - Universidade Federal do Espírito Santo, Brazil (co-author).
Main measurements and indices used in this study are as follow: LH, length of head; WH, width of head; WF, minimal width of frons; HE, height of eye; OOL, ocello-ocular line, the shortest distance from the eye top to the posterior ocellus; WOT, width of the ocellar triangle, including the ocelli; $\mathrm{DAO}$, diameter of anterior ocellus; VOL, vertex-ocular line, the distance from the eye top to vertex crest; LFW, length of forewing.

The nomenclature of integument sculpture follows Eady (1968) for the term coriaceous and Harris (1979) for the other textures. General terminology follows Evans (1964) and Azevedo (1999).

\section{Prosierola rotunda sp. nov. (Fig. 1)}

Description of type female length $6.75 \mathrm{~mm}$; LFW $3.2 \mathrm{~mm}$.

\footnotetext{
'Universidade Federal do Espírito Santo, Departamento de Biologia, Av. Marechal Campos 1468, Maruípe, 29.040-090 Vitória, ES, Brasil. (tataschiffler@hotmail.com, cazevedo@npd.ufes.br). ${ }^{2}$ Bolsista de iniciação cientifica $\mathrm{PIBIC/CNPq}$
} 


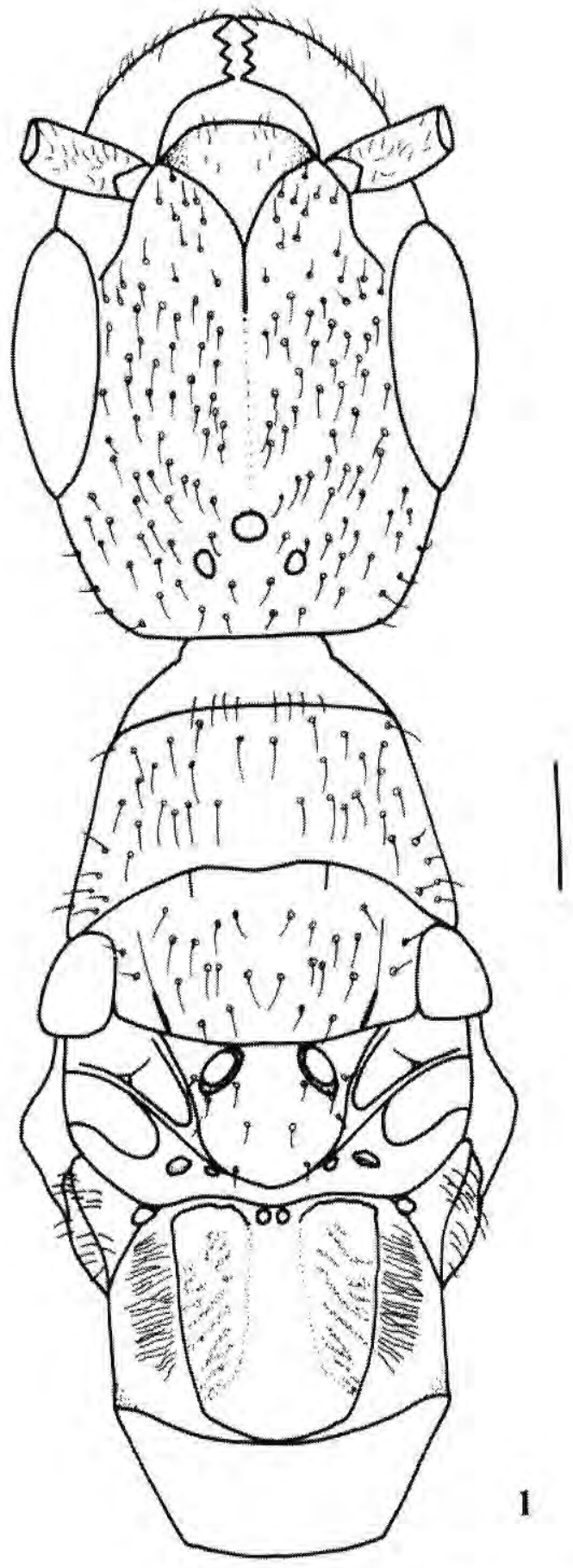

Figura 1. Prosierola rodunta sp. nov., head and mesosoma. (scale bar $=0.32 \mathrm{~mm})$. 
Color: head and mesosoma black, metasoma dark castaneous nearly black, clypeus dark castaneous, with apical border black, palpi, mandible, antenna, tegula and legs castaneous, wings subhyaline, forewing tinged with yellowish around the radian vein, stigma and veins castaneous.

Head: mandible tetradentate, the lower larger, the three upper closer each other. Clypeus with median lobe rounded, depressed and without median carina, forming a large reentrance in the region of contact with frons, which extends as a carina and becomes in a shallow groove up to the anterior ocellus. Antennae with some apical setae which stand out above the subapressed pubescence, first four antennal segments in a ratio of about 19:7:7:8, segment three and eleven each about 1.4 $\mathrm{X}$ as long as wide. Antennal scrobe carinate. Frons depressed, coriaceous, moderately shining, punctures shallow and large, separated each other by $1.5-$ $3 \mathrm{X}$ their own diameters. WH $1.01 \mathrm{X}$ LH, WF $0.60 \times$ WH, $1.32 \times$ HE, OOL $1.7 \mathrm{X}$ WOT; frontal angle of ocellar triangle right, posterior ocelli distant from the vertex crest 2.0 X DAO. Vertex broad, slightly convex.

Mesosoma: moderately coriaceous, with small, widely spaced punctures. Pronotal disc longer than mesoscutum. Mesoscutum angulate latero-posteriorly. Notauli little defined, present only in the anterior fifth. Parapsidal furrows weak, incomplete anteriorly and ill-defined medially. Scutellar pits deep, elliptical, inclined, separated each other by $1.0 \mathrm{X}$ their own maximum length. Propodeal disc
$1.46 \mathrm{X}$ as wide as long, its basal pits small, nearly touching each other; median area depressed, elevating weakly to the central area, with a few irregular striae on the sides, lateral area striate and abruptly elevated; transverse posterior carina strong and complete, lateral carina evident. Propleuron coriaceous. Mesopleuron gibbous on upper part, when seen from above much produced, not angularly, with a very large and deep pit.

Metasoma: polish, tergites and sternites with a posterior row of setae. Valvae densely hairy apically.

Material examined: holotype, female, Brazil, Amazonas, Manaus, Reserva 1208, 18.III.1986, Malaise trap col. (INPA). Paratype: 1 female, same data as holotype, except 08-X1985 (INPA).

Variation: paratype larger, LFW 3.37-3.62 mm; WH 1.02 X LH, WF 0.62 $\mathrm{X}$ WH, WF $1.33 \mathrm{X}$ HE; distance between the scutellar pits varies from 1.08$1.09 \mathrm{X}$ their own maximum diameters.

Remarks: this species is similar to P. lata (Cameron, 1888) and P. nasalis (Westwood, 1874), but it differs from them by having some peculiar characters, such as clypeus and frons depressed, median lobe of clypeus rounded, antennal scrobe conspicuously carinate. Male unknown.

Etymology: name refers to the median lobe of clypeus rounded.

\section{Prosierola lata (Cameron, 1888)}

This species was known from Tobago, Panama, Brazil (Mato Grosso and Santa Catarina) and Paraguay, and 
now it is recorded for the first time to the Brazilian states of Roraima, Amazonas, Espírito Santo and São Paulo. In this series, LFW from 2.8 to $3.5 \mathrm{~mm}$, specimens from Espirito Santo somewhat rufous at the thorax dorsum; clypeus usually testaceous with apical margin black, but dark brown in one specimen from Roraima; dorsal thorax coriaceous to polished (in one of the Roraima specimen); median carina of clypeus usually little arched in profile, but strongly in one specimen from São Paulo, carina continues on the frons as a faint line or soft depression to the anterior ocellus, however may be less conspicuous or even absent; WH 0.81.03 X LH; WF 1.21-1.53 X HE; OOL 1.36-1.7 X WOT; scutellar pits often slightly longer than wide and separated by from 1.0-2.0 X their own maximum diameters.

Material examined: BRAZIL, Roraima, 4 males, Rio Uraricoera, Ilha de Maracá, 2.V-30.IX.1987, Malaise trap, JA. Rafael, JEB. Brasil and team col. (INPA); Amazonas, 11 males, Manaus, Reserva 1208, 1112 and 1301, 30.X.1985-28.I.1987, Malaise trap, B. Klein col. (INPA); Espirito Santo, 2 males, Linhares, Reserva Florestal do Vale do Rio do Doce, 8.IX.199321.II.1994, I. Petzold col. (UFES); São Paulo, 3 males, Luiz Antônio, Estação Ecológica do Jataí, 16.X.198623.IX.1988, sweeping, LA. Joaquim col. (DCBU).

\section{Acknowledgements}

To curators of the collections for the loan of the studied material.

\section{Literature cited}

Azevedo, C.O. 1991. Comentário dos gêneros de Bethylidae (Hymenoptera, Aculeata) da região de São Carlos, SP, Brasil. Anais do Seminário Regional de Ecologia, 6: 483-496

Azevedo, C.O. 1999. Revision of the Neotropical Dissomphalus Ashmead, 1893 (Hymenoptera, Bethylidae) with median tergal processes. Arquivos de Zoologia, 35(4): 301-394.

Eady, R.D. 1968. Some illustrations of microsculpture in the Hymenoptera. Proceedings of the Royal Entomological Society of London (A), 43(3-6): 66-72.

Evans, H.E. 1964. A synopsis of the American Bethylidae (Hymenoptera, Aculeata). Bulletin of the Museum of Comparative Zoology, 132: 1-222.

Harris, R.A. 1979. A glossary of surface sculpturing. Occasional Papers in Entomology, 28: 1-31.

Aceito para publicação em 22/04/2002 